\author{
扁平母斑に対するルビーレーザーによる治療 \\ 舘下 亨，小野一郎 \\ 福島県立医科大学沿膚科（形成外科診療班） \\ T960-1295 福島県福島市光が丘 1 番地 \\ TEL $024-548-2111$ FAX $024-548-5412$
}

\title{
Treatment of Nevus Spilus Using Ruby Laser Systems
}

\author{
Tohru TATESHITA and Ichiro ONO \\ Division of Plastic and Reconstructive Surgery, \\ Department of Dermatology, Fukushima Medical University, School of Medicine \\ Hikarigaoka 1, Fukushima, Fukushima, 960-1295 JAPAN
}

\section{要 旨}

扁平母斑は組織学的に表皮底層におけるhypermelanosisのみの変化で真皮には病変を認め ない為, 皮虞剝削術, 冷凍療法, レーザー療法による治療効果が比較的容易に期待できるもの と考えられがちであるが，奏際には再発率が高く治療に難啮することが多い．

われわれは平成 2 年よりルビーレーザーによる扁平母斑の治療を始め, 治療法の検討を行っ てきた結果，以下の照射法をプロトコールにより治療し，良好な結果を得ることが可能になっ た。つまり，まずノーマル発振パルスルビーレーザー（ノーマルレーザー）による長パルス 30 〜 $40 \mathrm{~J} / \mathrm{cn}^{2}$ の照射により病変部を表皮虽離の状態とする. そのうえで生じた様爛面に更にノ一

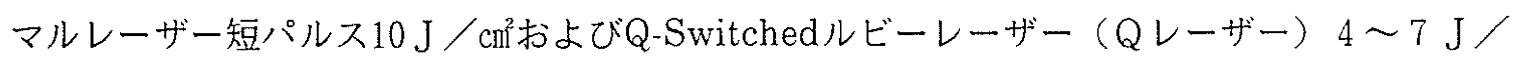
$\mathrm{cn}^{2}$ で追加照射をする．初回治療後 3 週間目に再発の有無にかかわらずノーマルレーザー短パル ス $10 \mathrm{~J} / \mathrm{cm}^{2}$ とQレーザー4〜 $7 \mathrm{~J} / \mathrm{cm}^{2}$ の照射を行うようにしている. 以上を 1 クールとし， 6 カ月程度の間隔で 2 クール以上の治療を行う。再発傾向の強い難治性の病例は未だ存在する が，以上のプロトコールにて治療することにより再発率を著しく低下させることができ，ほぼ 安定した結果が得られるようになってきた。

キーワード : 扁平母斑, ベッカー母斑, 皮虞色素異常症, ノーマル発振ルビーレーザー，Q スイッチ発振ルビーレーザー

\section{Abstract}

Nevus spilus is known to have a high recurrence rate against the various treatments. 
To minimize recurrence rate of the nevus, treatment was performed using a normal-pulsed ruby laser system (dual pulse width : $240 \mu \mathrm{sec} . \sim 1 \mathrm{msec}$.) as well as a Q-switched ruby laser system (pulse width : $30 \mathrm{nsec}$.). We treated the patients with nevus spilus using our protocol as indicated below.

After the epidermis on the treated area had been completely removed using long pulse of normal-pulsed ruby laser, the additional irradiation of short pulse with normal-pulsed ruby laser was performed and additional treament with Q-switched ruby laser treatment to whom the recurrence rate seems to be high. The protocol was further improved with additional laser treatment using short pulse of $10 \mathrm{~J} / \mathrm{cm}^{2}$ and Q-switched ruby laser treatment of $4 \sim 7 \mathrm{~J} / \mathrm{cm}^{2}, 3$ weeks after the first treatment even there is no visible recurrence on the treated area. We consider that at least 2 sessions of the treatment with our protocol are needed for establishing good results. The efficacy of ruby laser treatment on nevus spilus was judged as excellent of good in 69 out of 97 cases $(71.1 \%)$, and which has tendency to be improved as increasing treatment sessions. The side effects such as darkening of the lesion, ulceration, scar formation, or longstanding depigmentation were not observed.

Key words : nevus spilus, Becker's nevus, pigmented disorders of the skin, Normal -pulsed ruby laser, Q-switched ruby laser

緒 言

扁平母斑に対しては従来からの皮度剝削術，冷 凍療法、レーザー療法など ${ }^{-5)}$ の治療に加え,レー ザーによる治療が検討されているもののなお再発 率が高く充分な効果をあげるのが困難な状況で あった。 一方で従来の方法では真皮内にメラニン を持つために治療効果が低かった太田母斑におい てQ-switchedルビーレーザー，Q-switchedアレ キサンドライトレーザー, Q-switched Nd-YAG レーザーなどの開発や応用により，極めて高い有 効性が得られるようになってきている6-15)。こ の点からもより効果的な扁平母斑に対するレー ザー治療の確立が待望されている.

我々は発振パルス幅を $1 \mathrm{msec}$. $240 \mu \mathrm{sec}$. へ と変換可能なノーマル発振ルビーレーザー（ノー マルレーザー）とQ-switched 発振ルビーレー ザー（Qレーザー）を用いて我々の独自のプロト コールで本疾患の治療を行い，比較的良好な結果 を得られたので若干の考察を加え報告する.
方法亡対象

\section{1）レーザー照射装置}

使用したレーザー装置は東芝メディカル社製の ノーマルレーザー, LRT-301 A とQレーザー, LRT-301 A / QSの 2 種類である（図 1 ）。 ノ一 マルレーザーは，発振波長が $694 \mathrm{~nm}$ で発振パル ス幅 $1 \mathrm{msec}$. (長パルス)，エネルギー密度10〜 $40 \mathrm{~J} / \mathrm{cni}^{2}$ 亡発振パルス幅 $240 \sim 400 \mu \mathrm{sec}$.（短パル ス)、エネルギー密度 $5 \sim 30 \mathrm{~J} / \mathrm{cm}^{2}$ の両者が選択可 能な機器である.一方, Qレーザーは，Q-switch 発振により発振パルス幅が30nsec，と極めて短 かく，エネルギー密度が $2 \sim 7 \mathrm{~J} / \mathrm{cm}^{2} に$ 調整可能 な機器である.

両機種ともハンドピースにはカライドコープを 使用しており，照射野が正方形である上その照射 野全体に均一なエネルギー分布により照射可能で あるというのが特徵である(1)。 ノーマルレー ザーの照射野の大きさは10×10m 之 $15 \times 15 \mathrm{~mm}$ で,

Qレーザーの方は $4 \times 4$ mmのサイズ加え，特注 のスコープにより，比較的大きな $5.5 \times 5.5 \mathrm{~mm}$ のサ 
イズも選択できる。

2) レーザー照射法

レーザー照射中は術者は使用波長にあった保護 眼鏡をかけ，患者には同様に保護眼鏡またはガー ゼにてレーザー光を遮光した．眼瞼の周囲の照射 の際にはシリコン製のコンタクトシェルを挿入し て眼球保護につとめた。

治療にあたってはハンドピースを皮虞面に垂直 に把持し、未照射部が残存せずスポット辺縁が オーバーラップするように移動させながら注意哚 く照射した。

治療法の詳細は以下の通りである.

まずノーマルレーザー長パルス $30 〜 40 \mathrm{~J} / \mathrm{cm}^{2} の$ 照射により病変部を表皮剥離の状態とする．その 際, 色調の濃度によりエネルギー密度を適宜選択

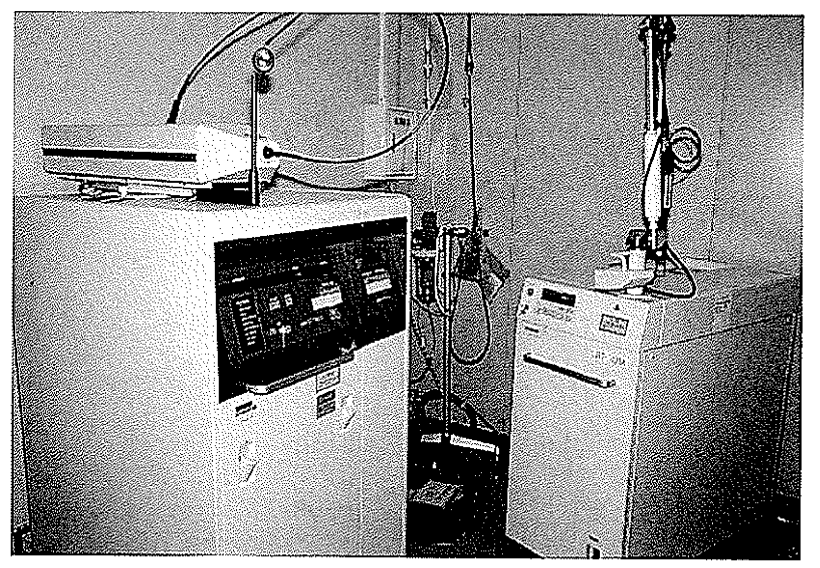

図 1 レーザー照射装置

（左側：LRT-301A，右側：LRT-301A / Q.S).
する.つまり色調の濃いものでは低めのエネル ギー密度を, 色調の薄いものでは高めのエネル ギー密度を選択する，表皮は照射後，ガーゼを用 いて用手的に除去して完全に除去することが重要 である。そのうえで生じた様爛面に更にノーマル レーザー短パルス $10 \mathrm{~J} / \mathrm{cn}^{2} て ゙$ 追加照射をする，再 発傾向の強い症例において，最近ではさらにQ レーザー 4〜 $7 \mathrm{~J} / \mathrm{cm}^{2}$ の重複照射も行っている. その後, 通常病变部は5〜 7 日前後で表皮化する が, 初回治療後 3 週間目に再発の有無にかかわら ずノーマルレーザー短パルス $10 \mathrm{~J} / \mathrm{cm}^{2}$ ¿ Q Q ザー4〜 $7 \mathrm{~J} / \mathrm{cm}^{2} の$ 照射を行うようにしている. つまり長パルスのノーマルレーザーの照射 1 回, 短パルスノーマルレーザーとQレーザーそれぞれ 2 回の治療が1クールの治療之なる。（図 2).そ の後, 2 クール目の治療は最低 $3 \sim 6$ 力月経過を 観察した上で開始するようにしている。.2クール 目以降も以上述べた 1 クール目と同様の治療を繰 り返すが，再発傾向が署明な症例には初回照射と 2 回目の追加照射の治療間隔を本来は 3 週間目之 設定しているところを，1週間ないし10日に短縮 させ同治療を繰り返すことにしている。

いずれの治療後も5日間ないし 1 週間，抗生剂 含有ワセリン基材軟暨を上皮化が終了するまで塗 布し，その後はガーゼとテープあるいは遮光ク リームによる遮光を最低 3 力月間行った。

本プロトコール1クール

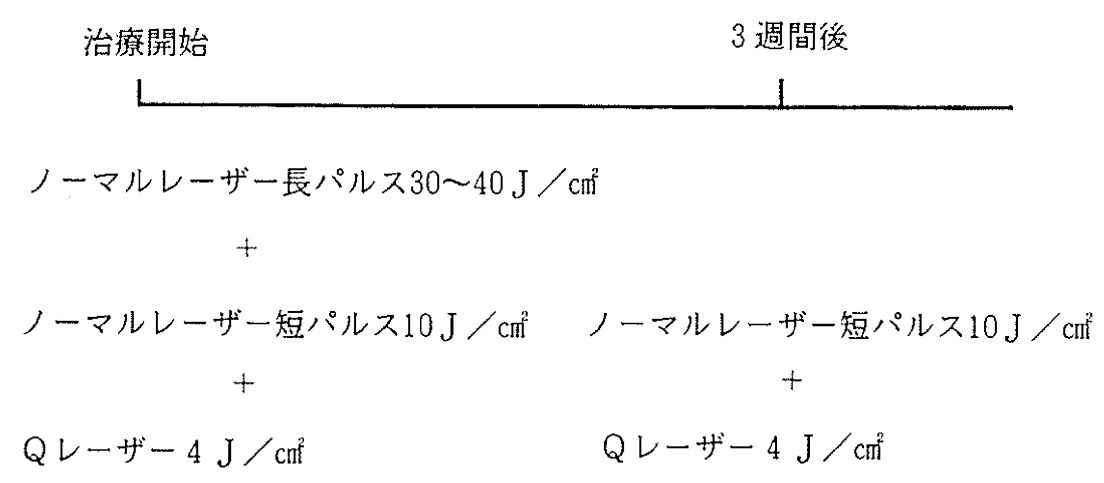

図 2 当科における治療プロトコール 


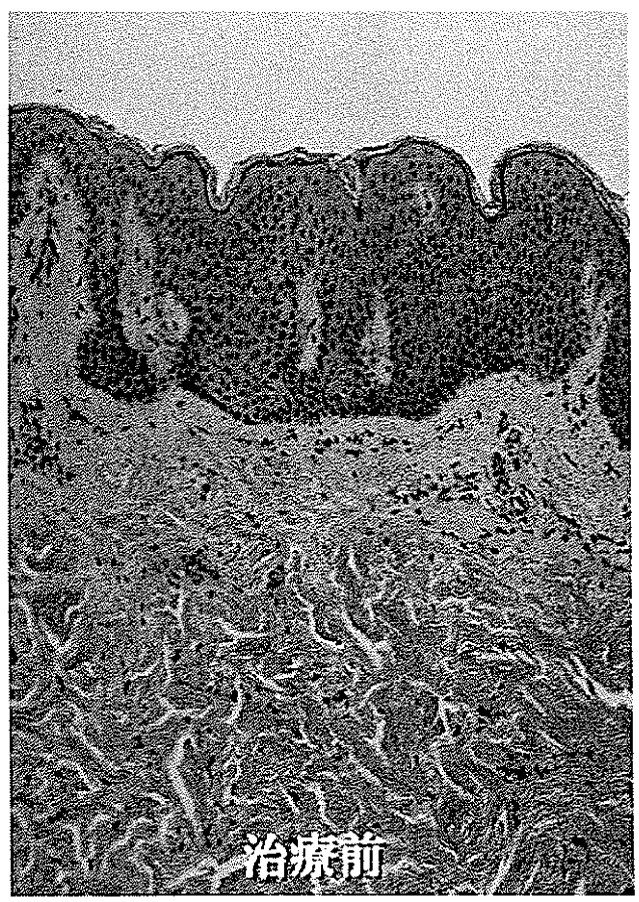

a

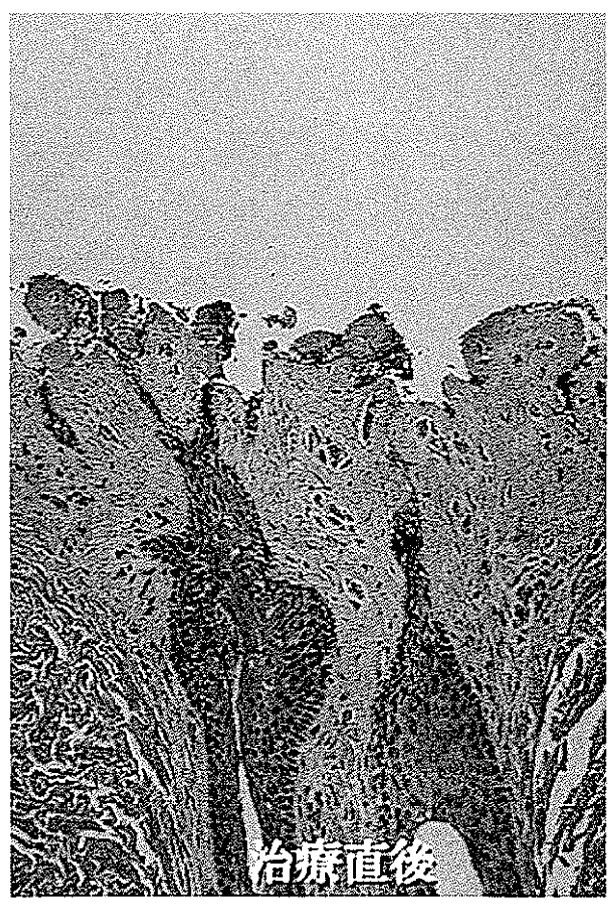

b

図 3

a. 照射前.

b.ノーマルレーザー長パルス30 J / $\mathrm{cm}^{2} て ゙$ 表皮を除去したうえで, 追加照射としてノーマルレーザー 短パルス10 J $/ \mathrm{cm}^{2} の$ 照射を行い， Qレーザー $4 \mathrm{~J} / \mathrm{cm}^{2}$ の照射を行った直後の状態.

\section{3) 組織学的検討}

扁平母斑は表皮基底層におけるhypermelanosisのみの変化で真皮には病变を認めないが（図 3 a ), レーザー照射直後においては表皮が䟝離 されている.毛襄は残存しているものの毛襄上部 にはレーザー照射の効果が認められる（図 3 b）。

\section{結 果}

最終照射治療完了後 6 力月以上経過している 97 症例に対して前述の方法で治療効果の評価を行っ た. 治療効果の評価の結果, 症例全体では, excellentが30例 (30.9\%), goodが39例 (40.2\%), fair が23例 (23.7\%), no changeが 5 例 (5.2 $\%)$, poorが 0例 $(0 \%)$ 之, good以上の有効 例は69例（71.1\%）であった，尚，いずれの症例 においても潰瘍化，痏痕形成および長期におよぶ 脱色素斑などの副作用は認められなかった。

以下代表症例の経過について述べる.

症例 1：11歳, 女性, 右煩部の扁平母斑（図 4 a).
生来右頓部に扁平母斑を認めた。 長パルス 30 $\mathrm{J} / \mathrm{cm}^{2}$ 表皮を除去したうえで，追加照射として 右下部にノーマルレーザー短パルス $10 \mathrm{~J} / \mathrm{cm}^{2} の$ 照 射を行い，Qレーザー $4 \mathrm{~J} / \mathrm{cm}^{2} の$ 照射を併用した。 その後 3 週間後の時点では再発は認められなかっ たものの，さらに追加照射をノーマルレーザー短 パルス $10 \mathrm{~J} / \mathrm{cm}^{2}$ およびQレーザー $4 \mathrm{~J} / \mathrm{cm}^{2}$ の照射 を行った，その後，外来通院にて経過を観察して いたが，治療開始後 4 力月に両照射野之も軽度の 再発は認めたものの色素斑の面積は縮小した。 そ こで更に母斑全体に対し長パルス $30 \mathrm{~J} / \mathrm{cm}^{2}$ で表皮 を除去したうえでノーマルレーザー $10 \mathrm{~J} / \mathrm{cm}^{2} お よ$ びQレーザー $4 \mathrm{~J} / \mathrm{cm}^{2} の$ 重複照射を行ったところ， 治療開始上り 4 年 1 力月, 本治療 2 クール目の治 療後 3 年 5 力月の時点で再発は認められず良好な 結果が得られている(図 4 b).

症例 2 : 15歳, 女性, 左肩のベッカー母斑（図 5 a).

生来左肩に $25 \times 17 \mathrm{~cm}$ 大のベッカー母斑を認めた. この症例においては1クール目にはノーマルレー 


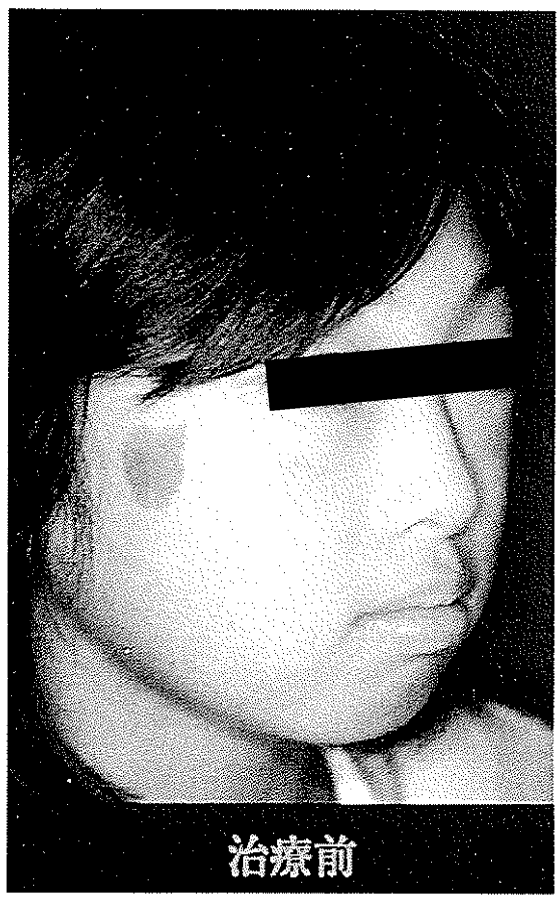

a

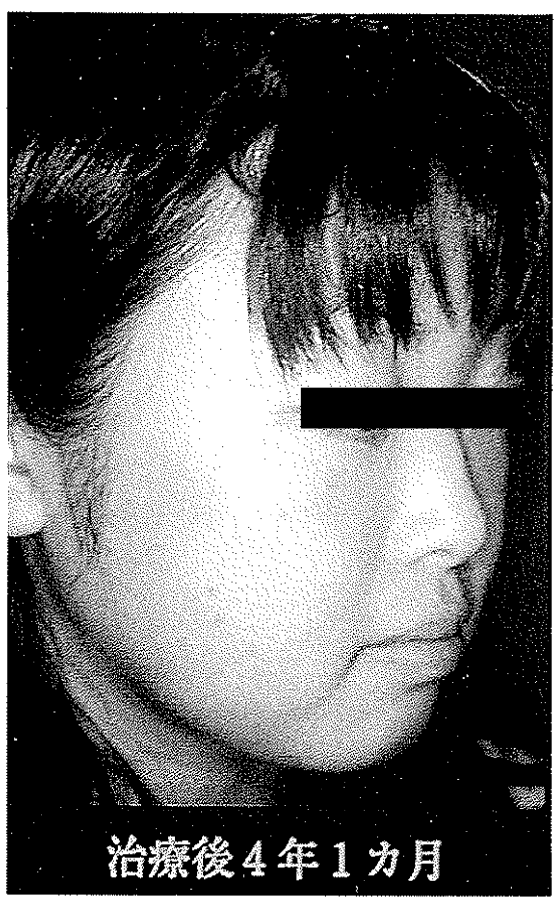

b

図 4 右頓の扁平母斑

a、照射前.

b. 治療開始後 4 年 1 力月, 本治療 2 クール目の治療個 3 年 5 力月の状態

ザー長パルス $30 \mathrm{~J} / \mathrm{cn}^{2} て ゙$ 表皮を除去したうえで， 追加照射としてノーマルレーザー短パルス10 J / $\mathrm{cm}^{2}$ のみ行いQレーザーの治療は行っていないが, 2 クール目からノーマルレーザー長パルス $30 \mathrm{~J} /$

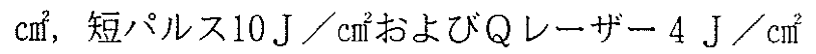
の追加照射を施行した．最終照射後 2 年 2 力月経 過しているが比較的良好な状態である（図 5 b).

症例 $3 ： 37$ 歳, 男性, 右大腿部の扁平母斑（図 6 a).

生後 6 力月目より発症した淡褐色調の扁平母斑 を右大腿部に認めた。治療にあたり，まず，長パ ルス $30 \mathrm{~J} / \mathrm{cm}^{2}$ 表皮を除去したうえで，追加照射

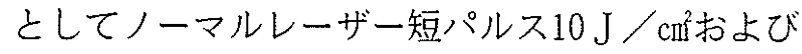
Qレーザー $7 \mathrm{~J} / \mathrm{cm}^{2}$ の照射による治療を行った。 さらにその後 3 週間目にノーマルレーザー短パル

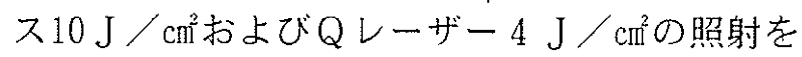
行った. 治療後 9 力月目でやや再発を認めるが今 後 2 クール目の治療を予定している（図 6 b).
考 察

ルビーレーザーがMaimanによって開発さ $れ^{16)}$, Goldmanらがルビーレーザーを用いて 入北墨の治療を行って以来 ${ }^{17}{ }^{18)}$, 皮䖉の色素異 常症に対するルビーレーザー治療は臨床応用が進 んできた. 1983年にはAndersonらが提唱した selective photothermolysis ${ }^{(9)}$ おうよびthermal relaxation time ${ }^{20)}$ などの概念により Qスイッ チレーザーの臨床応用が盛んとなり，その後の諸 家の検討により太田母斑に対しては極めて良好な 治療成績が得られるようになった して，表皮基底層のみに病变を認める扁平母斑に 対しては，ドライアイス圧抵法，剝削術，外科的 切除術などが試みられ(6-15)，また最近はレー ザーによる治療も試みられているがいずれも未だ 再発, 瘏痕形成, 脱色素斑などの形成が多く21), その確奉な治療法が未だ確立されておらず，再発 を防ぐ方法が模索されているのが現状であった。 われわれは治療成績が必ずしも充分でなかった顔 面および頚部における扁平母斑に対し，すでに報 


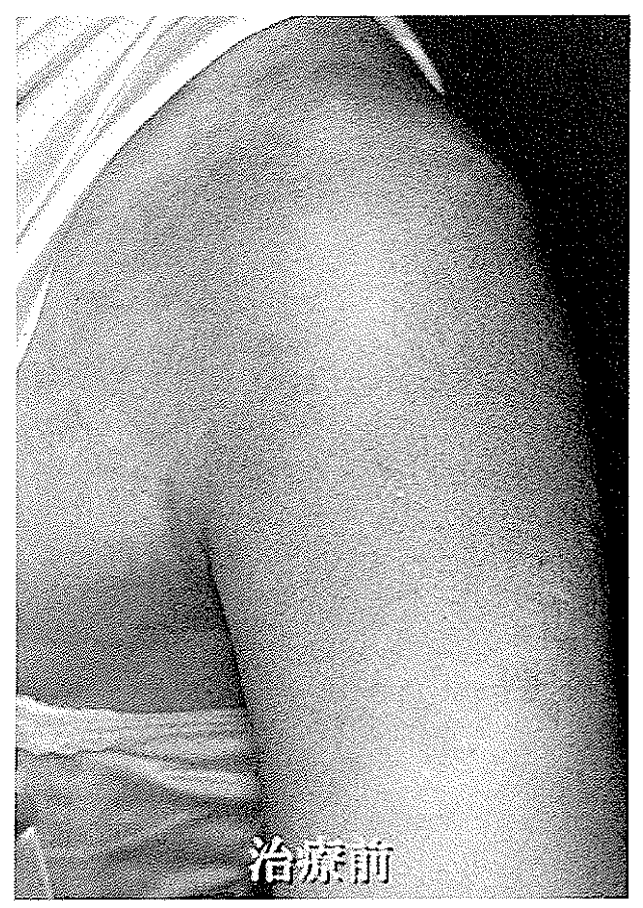

a

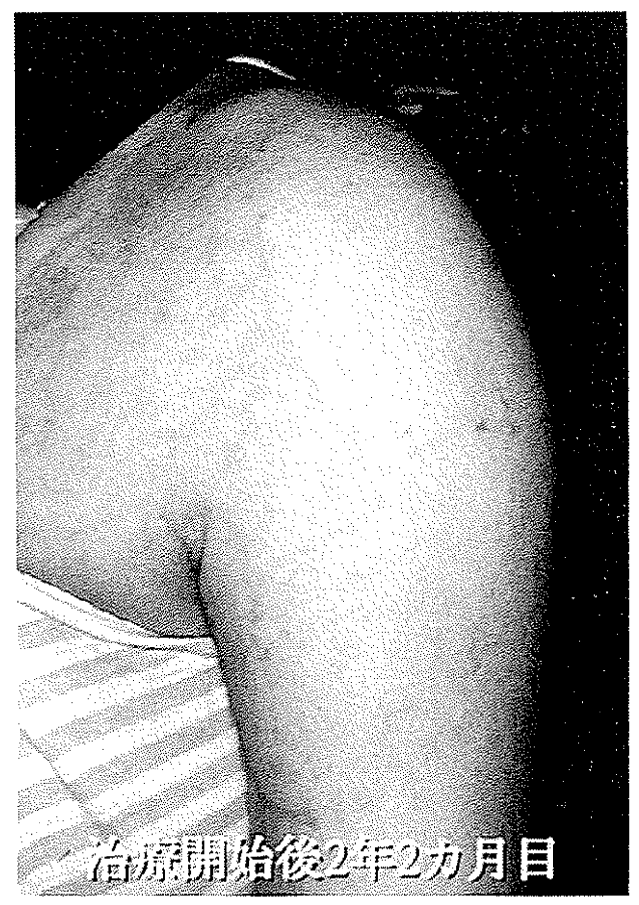

b

図 5 左型の扁平母斑 (ベッカー母斑)

a. 照射前。

b. 治療開始後 2 年 2 力月の状態.

告しているように21-25)，ノーマルレーザーにて 2クール程度同様の治療を繰り返す従来の我々の 方法に加え, 最近では再発を防ぐ目的で $Q$ レー ザーの追加照射を行うといったプロトコールに基 づいた治療を試みている．まず長パルス $30 〜 40$ $\mathrm{J} / \mathrm{cm}^{2}$ で病变部を 1 ないし 2 回照射して表皮䟝離 の状態とする，次いで表皮を用手的に完全に除去 した上で，生じた糜爛面にさらにノーマルレー

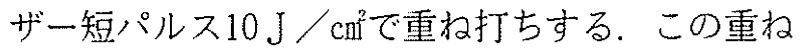
打ちの目的は、再発の一要因之考えられる真皮内 に残存する外毛根鞘などのメラノサイトを变性さ せることである。この際，表皮剝離の状態にする ことにより追加照射するノーマルレーザー短パル ス $10 \mathrm{~J} / \mathrm{cm}^{2}$ およびQレーザー $4 \sim 6 \mathrm{~J} / \mathrm{cm}^{2}$ の有効 性が最大限になるものと考えて治療を行ってい る22.23).なお, メラニンの量と照射するエネル ギー量のそれぞれに照射後に発生する熱エネル ギー量が比例することから，初回の照射エネル ギー密度は病変の色調が濃いものでは低く, 薄い ものでは高く設定する方が病变の周囲の正常皮䖉
への傷害を最低限にでき，より選択的な治療を施 行するためには良いと考えている，本治療後は通 常 5 日間前後で表皮化するが，その後は注意深く 遮光を行う。わ执扎は通常治療後 3 週間目位迄 に表皮化が終了した病変部に再発の有無にかかわ らずノーマルレーザー短パルス $10 \mathrm{~J} / \mathrm{cm}^{2} お$ よび $\mathrm{Q}$ レーザー 4〜 $7 \mathrm{~J} / \mathrm{cm}^{2}$ の追加照射するようにして いる.この治療を $2 \sim 3$ クール以上， $3 \sim 6$ 力月 間の間隔で繰り返すことにより治療効果が向上す るものと考えている.

再発率は治療部位の毛襄の樑さや皮虞の厚さが 再発に影響しているものと考えられ”，実際の症 例でも顔面や頚部においては内・外眼角部や口角 部など皮虏付属器が多く存在すると思われる部位 において再発傾向が強い上うであった．再発の機 序としては扁平母斑内のメラノサイトは易刺激性 でメラニンを作りやすく，その結果，基底細胞に メラニン色素の増加が生じるのではないかとの報 告があるが4，レーザー照射による变性を受けな かったエクリン汗腺, 外毛根鞘なよ゙から再発して 


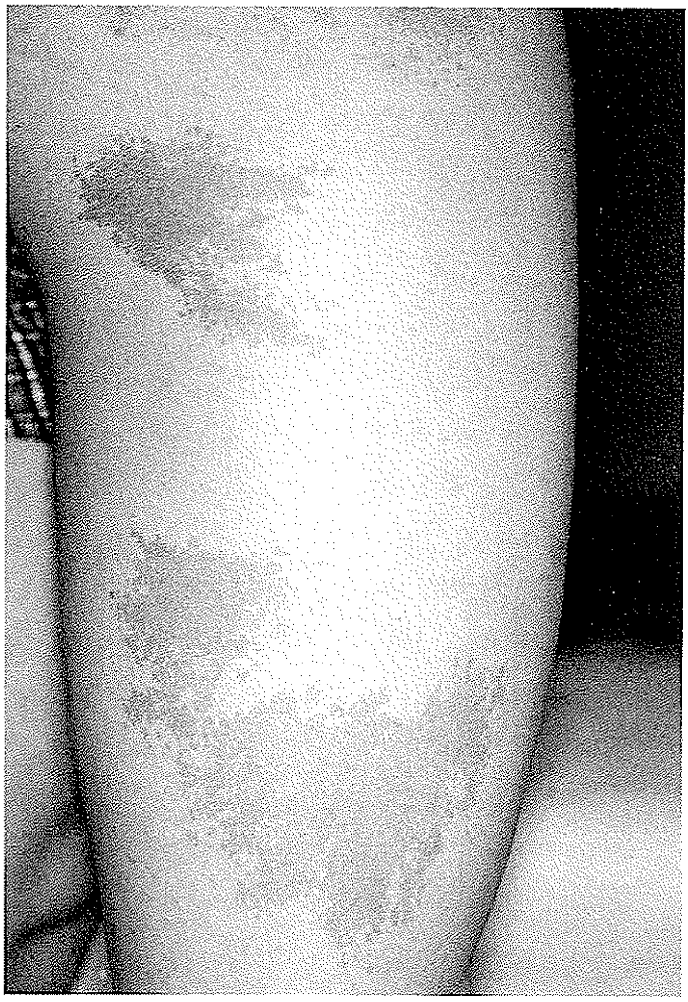

a

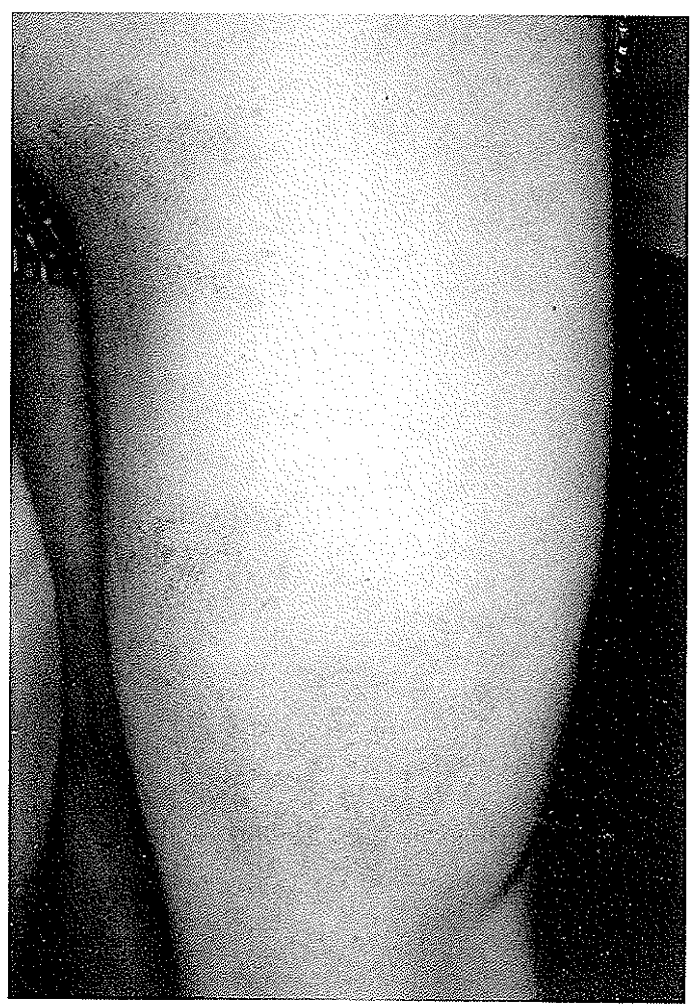

b

図 6 右大腿の扁平母斑

a. 照射前.

b. 治療開始後 9 力月の状態.

くるのではないかとの考えもあり10.23)，その詳 細は未だ明らかではない，奏際にはメラニン産生 細胞の形態ならびに動態，これら細胞と皮豦附属 器, 殊にエクリン汗腺との関連性について明らか な見解はない，しかしエクリン汗管内にDOPA 反応陽性メラノサイトの存在やエクリン汗管壁に もメラニン産生細胞が認められ，再生表皮の基底 層には 3 週目から樹脂状メラニン産生細胞が確認 されるとの報告 ${ }^{26)}$ もある。 それらを考慮すると 3週間目位迄に表皮化が終了した病変部にノーマ

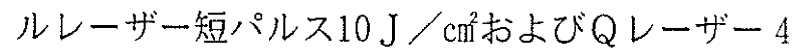
〜 $7 \mathrm{~J} / \mathrm{cm}^{2}$ の追加照射を行うことが再発を抑える 上で非常に有効なのではないかということが示唆 される。この際，われわれは短パルスのノーマル レーザーの追加照射は比較的浅い外毛根鞘を破壊 し，Qレーザーは更に深部にある毛襄のメラニン 産生細胞を破壊する上で有効であると推測してい る. また再発傾向の強い症例においては次第に再 発する病变部の面積の縮小化や色調の減弱化を認
め, 2〜 3クール前後の治療を行うことにより 1 クールのみの治療に比較して劇的に良好な結果が 得られる。この機序として，1クールの治療時に 休止期である毛襄におけるメラニン産生細胞は レーザーによる变性を受けず, 数力月後生成期の 毛讋として再発に関与するが，更にレーザー照射 を繰り返すとレーザー照射の効果を与えることが でき，それらを繰り返すことにより次第に再発率 の低下が起こるものと推測している。しかし，本 プロトコールを用いても治療効果には未だ限界が ある，特に若年者の扁平母斑の再発率は成人のそ れよりも高いことが確認されており，今後は治療 開始時期についても再検討が必要上考えている.

\section{結 論}

当科の治療プロトコールにて治療することによ りルビーレーザーの治療で扁平母斑において比較 的優れた治療効果を得ることができた。そのうえ で，Qレーザーの追加照射は再発率を低下させる 
上で有用であると考えられた，また，再発率は1 クールのみの治療では高かったが 2 クール上治 療した症例では大幅に低下した。再発には休止期 の毛襄か関与している可能性が高いと考えられる. 我々の治療プロトコールを 2 度ないし 3 度治療 を繰り返すことにより再発率が低下し, 顔面, 頚 部の病変，さらには四肢の病変においても良好な 治療効果が得られることを明らかとした。

\section{参考文献}

1) 平山峻, 鈴木 隆, 牧野玲子, 村山清子: 扁平母 斑に対するわ㧈わ机の治療法. 形成外科，32：265 $\sim 274,1989$.

2) 大久保文雄, 武田 仁, 山口明伸, ほか: Q スイッ チルビーレーザーに上る皮府色素疾患の治療－第 1 報一。 日形会誌, $14: 104 \sim 115,1994$.

3) 袖井文二, 奈良 卓, 湊 祐廣, ほか: 各種母斑に 対する冷凍㙩法の検討，岩手医誌，46：89～95， 1994.

4) 手塚 正, 佐伯光義, 楠田茂, 梅本和義: 扁平母 斑に対する治療の試み，第 1 報：顔面の扁平母斑に 対する皮履剝削街および色素レーザー照射法の長期 観察結果. 西日皮府，55：98～105，1993.

5）塚田貞夫, 赤羽紀子, 飛見昭子：遅発性扁平母斑 - 100 例の解析と治療について一皮䖉科の臨床, $13: 181 \sim 191,1971$.

6 ) Geronemus, R. G. Q-switched ruby laser therapy of nevus of Ota. Arch. Dermatol. . 128: 1618-1622, 1992.

7) 林 洋司, 安田幸雄, 塚田貞夫：Qスイッチアレキ サンドライトレーザーによる太田母斑の治療, 日形 会誌, $14: 753 \sim 782,1994$.

$8)$ Laub, D. R., Yules, R. B., Arras, M. et al. : Preliminary histopathological observation of Q-switched ruby laser radiation on dermal tattoo pigment in man. J. Surg. Res., $8: 220$ $224,1968$.

9 ) 宮坂宗男, 谷野隆三郎, 長田光博: 色素性皮椨疾患 に対するレーザーの基礎と臨床. 日本レーザー医学 会誌, $11: 117-127,1991$.

10) Ohshiro, T.: Ruby laser treatment. Laser treatment for nevi. edited by T. Ohshiro, 56-59, Medical Laser Reserch Co., Tokyo, 1980.

11) 大塚壽, 中岡啓喜, 渡部隆博, 岡山直靖: 母斑之 その類症に対するルビーレーザー治療，形成外科，
$34: 615-623,1991$.

12) Ono, I., Gunji, H., Sato, M. et al.: Treatment of pigmented seborreic keratosis by ruby laser irradiation. Eur. J. Dermatol. 3 : 206-211, 1993.

13) Polla, L. L., Margolis, R. J., Dover, J. S. et al.: Melansomes are a primary target of $\mathrm{Q}$ switched ruby laser irradiation in guinea pig skin. J. Invest. Dermatol., 89 : 281-286, 1987.

14）鈴木 隆：Qスイッチヤグレーザーによる太田母斑 の治療. 日形会誌, 15:238 252, 1995.

15) Watanabe, S., Takahashi, H.: Treatment of nevus of Ota with the Q-switched ruby laser. New Eng. J. Med., 331 : 1745-1750, 1994.

16) Maiman, T. H.: Stimulated optical radiation in ruby. Nature, 4736: 493-494, 1960.

17) Goldman, L., Blaney, D. J., Kindel, D. J., Franke, E. K.: Effect of the laser beam on the skin, Preliminary report. J. Invest. Derm., $40: 121-122,1963$.

18) Goldman, L., Wilson, R. G., Hornby, P., Meyer, R. G.: Radiation from a Q-switched ruby laser, Effect of repeated impacts of power output of 10 megawatts on a tattoo of man. J. Invest. Derm., $44: 69-71,1965$.

19) Anderson, R. R., Parrish, J. A.: Selective photothermolysis, Precise microsurgery by selective absorption of pulsed radiation. Science, $220: 524-527,1983$.

20) Parrish, J. A., Anderson, R. R., Harrist, T. et al.: Selective thermal effects with pulsed irradiation from lasers, from organ to organelle. J. Invest. Dermatol., 80:75-80, 1983.

21）小野一郎, 郡司裕則, 有賀媇二ほか：ルビーレー ザー照射後の皮㢈の病理学的变化. 日本レーザー医 学会誌, 11：99-106, 1991.

22）小野一郎，郡司裕則，須田和義ほか：パルス幅を短 縮したルビーレーザーの皮葓の色素異常症に対する 効果. 形成外科， $36: 285-296 ， 1993$.

23) Ono, I., Gunji, H., Tateshita, T., et al.: Treatment of nevus spilus using a ruby laser system with a dual pulse width. Eur. J. Dermtol., 5 : 371-378, 1995.

24）佐藤守弘, 郡司裕則, 小野一郎, 金子史男：ルビー レーザーのパルス幅の差による皮虞の病理組織学的 变化についての検討。臨床皮成科，47：537-540, 1993.

25）小野一郎：ルビーレーザーの基礎上臨床. 形成外科 ADVANCEシリーズIIー2レーザー治療：最近の 
進歩, 長田光博, 菊地眞編, $97 \sim 115$, 克誠堂出版,

東京, 1997 .

26）今川一郎：色素細胞母斑皮痛䟝削術後の再発機序に

ついて一点状集蔟性母斑の再生色素斑に関する研究

一. 日皮会誌. $86: 273 \sim 287,1974$. 